Karuniawan, A $\cdot$ H.N. Wicaksono $\cdot$ D. Ustari $\cdot$ T. Setiawati $\cdot$ T. Supriatun

\title{
Identifikasi keragaman genetik plasma nutfah ubi kayu liar (Manihot glaziovii muell) berdasarkan karakter morfo-agronomi
}

\section{Identification of genetic diversity of wild cassava (Manihot glaziovii muell) germplasm based on morpho-agronomy traits}

Diterima : 11 Desember 2017/Disetujui : 18 Desember 2017 / Dipublikasikan : 30 Desember 2017

CDepartment of Crop Science, Padjadjaran University

\begin{abstract}
Plant germplasm is a source of genetic material for plant breeding programs. The objective of this research was to identify genetic diversity of wild cassava germplasm based on morpho-agronomy character. This experiment was conducted from December 2014 to June 2015. This experiment was arranged in Randomized Block Design (RAK) with 23 accessions of wild cassava and repeated twice. The principal component analysis was displayed in biplot and percentage of contribution in three PC. The characters contributing to the variations contained in the accessions include pubescence on apical leaves, shape of central leaf, leaf lobes number, lobe margins and petiole color. The cluster analysis generated two mail cluster that showed in dendogram image, namely I and II. The range of euclidean distance in the dendogram image was from 0.00 to 3.32. This result indicated widely variation among Unpad wild cassava germplasm.
\end{abstract}

Keywords: Principal Component Analysis, Cluster Analysis, Biplot, Dendogram, Genetic Diversity, Cassava

Sari Plasma nutfah tanaman merupakan sumber bahan genetik bagi program pemuliaan tanaman. Penelitian ini bertujuan untuk mengidentifikasi keragaman genetik plasma nutfah ubi kayu liar berdasarkan karakter morfoagronomi. Percobaan dilaksanakan pada bulan

\footnotetext{
Dikomunikasikan oleh Sosiawan Nusifera

Karuniawan, A. ${ }^{1} \cdot$ H.N. Wicaksono ${ }^{2} \cdot$ D. Ustari ${ }^{3} \cdot$ T.

Setiawati ${ }^{4} \cdot$ T. Supriatun ${ }^{4}$

1) Staf pengajar di Fakultas Pertanian UNPAD

2) Alumni Program Sarjana Agroteknologi UNPAD

3) Alumni Program Pascasarjana Agronomi UNPAD

4) Staf Pengajar di Fakultas Matematika dan Ilmu

Pengetahuan Alam UNPAD

Korespondensi : agung.karuniawan@unpad.ac.id
}

Desember 2014 hingga Juni 2015. Percobaan disusun dalam Rancangan Acak Kelompok (RAK) dengan perlakuan 23 aksesi ubi kayu liar dan diulang sebanyak dua kali. Analisis komponen utama menghasilkan biplot dengan analisis komponen utama PC1 pada aksesiaksesi ubi kayu liar yang dievaluasi mempunyai kontribusi proporsi variasi total sebesar 63.4192 $\%$ pada PC3, karakter-karakter yang berkontribusi terhadap variasi yang terdapat pada aksesi-aksesi tersebut meliputi bulu daun apikal, bentuk daun, jumlah lobus daun, jarak lobus dan warna tangkai daun. Analisis klaster menghasilkan gambar dendogram terdiri dari dua klaster utama yaitu I dan II. Pada gambar dendogram terdapat jarak euclidean antara 0.00 hingga 3.32. Hal ini menunjukan bahwa plasma nutfah ubi kayu liar Unpad adalah luas.

Kata Kunci : Analisis Komponen Utama, Analisis Klaster, Biplot, Dendogram, Keragaman genetik, Ubi Kayu Liar.

\section{Pendahuluan}

Ubi kayu liar (Manihot glaziovii Muell) merupakan kerabat liar ubi kayu budidaya (Manihot esculenta). Ubi kayu liar dapat dengan stabil berproduksi pada musim panas dan dalam keadaan kekurangan air sekalipun (George dan Reghu, 1993). Pemanfaatan ubi kayu liar di Indonesia umumnya hanya diambil daunnya sebagai sayuran, sedangkan ubinya jarang dimanfaatkan dalam kehidupan seharihari karena memiliki rasa yang pahit. Ubi kayu liar memiliki kandungan karbohidrat tinggi yakni sebesar 98,5\%, namun ubi kayu liar mengandung unsur kimia asam sianida $(\mathrm{HCN})$ yang bersifat racun sehingga selama ini 
pemanfaatan ubi kayu liar hanya sebatas batang bagian atas dengan disambungkan pada batang varietas ubi kayu budidaya pada bagian bawahnya (Hapsari dan Pramashinta, 2013). Teknik semacam ini biasa disebut dengan mukibat. Budidaya ubi kayu mukibat telah lama dikenal namun cara tersebut tidak berkembang.

Kandungan pati ubi kayu liar dapat diolah menjadi bioetanol untuk bahan bakar kendaraan dengan melewati beberapa proses terlebih dahulu (Hapsari dan Pramashinta, 2013). Kandungan oktan dalam bioetanol ubi kayu liar diketahui sebesar 118, angka tersebut melampaui kandungan oktan tertinggi bahan bakar Pertamax Plus yakni sebesar 95 (Firdausi dkk, 2013). Permintaan ubi kayu sebagai bahan bakar bioetanol meningkat, hal tersebut membuat budidaya ubi kayu mukibat lebih dikembangkan. Sucahyono dkk, (2010) menyebutkan bahwa hasil ubi kayu mukibat di KP Genteng mencapai 90,4-99,67 ton/ha, sedangkan dengan cara budidaya biasa menghasilkan 54,3-61,87 ton/ha.

Peningkatan produksi ubi kayu liar dalam program pemuliaan tanaman pada saat ini masih terkendala. Salah satu faktor yang menyebabkan hal tersebut karena belum diketahui keragaman gentik ubi kayu liar. Ubi kayu liar biasanya tumbuh liar di ladang-ladang pertanian tanpa dibudidayakan, oleh karena itu, perlu dilakukan penelitian mengenai identifikasi keragaman gentik plasma nutfah ubi kayu liar. Tujuan dari identifikasi keragaman genetik adalah untuk mengetahui keragaman aksesi ubi kayu liar berdasarkan karakter morfo-agronomi. Keragaman genetik ubi kayu liar dianalisis melalui analisis komponen utama dan analisis klaster. Analisis komponen dilakukan untuk menilai sejauh mana kontribusi suatu karakter terhadap keragaman aksesi ubi kayu liar dan analisis klster dilakukan untuk melihat kekerabatan dari kumpulan data yang diperoleh. Semakin dekat kekerabatan ubi kayu liar maka semakin sempit tingkat keragamannya. Begitupun sebaliknya, semakin jauh kekerabatan ubi kayu liar maka semakin luas tingkat keragaman gentiknya.

Keberhasilan dalam upaya mendapatkan karakter yang diinginkan adalah bergantung pada adanya keragaman genetik tanaman yang tinggi atau luas. Keragaman genetik ubi kayu liar yang luas akan memudahkan proses seleksi dan persilangan. Memperbanyak variasi suatu komoditas tanaman dapat dilakukan dengan cara melakukan persilangan antar spesies tanaman dalam satu genus namun harus dilihat apakah genetik yang dimiliki spesies tersebut seragam atau tidak. Menurut Martono (2011), keragaman genetik yang luas berarti terdapat genotipe yang berbeda dalam suatu populasi. Genotip-genotip yang bersifat heterozigot melakukan penyerbukan sehingga keturunan yang dihasilkan akan beragam. Keragaman genetik cukup besar pada tanaman menyerbuk silang dibandingkan dengan tanaman menyerbuk sendiri (Marlitasari, 2012). Keragaman genetik tinggi mampu menghasilkan kemungkinankemungkinan variasi genetik tanaman unggul baru.

Universitas Padjadjaran kini menjadi salah satu pelopor pengembangan ubi kayu liar untuk dapat meningkatkan produktivitas ubi kayu budidaya di Indonesia. Diharapkan dengan penelitian ini didapatkan aksesi ubi kayu liar yang mampu menunjang produksi ubi kayu budidaya skala nasional dan diharapkan dapat membantu mengidentifikasi tambahan koleksi plasma nuftah di Indonesia.

\section{Bahan dan Metode}

Percobaan ini dilaksanakan di Kebun Percobaan Ciparanje Fakultas Pertanian Universitas Padjadjaran, Kecamatan Jatinangor, Kabupaten Sumedang, Jawa Barat. Lokasi tersebut memiliki ketinggian tempat $\pm 753 \mathrm{~m} \mathrm{dpl}$, dengan curah hujan tipe C menurut Schmidt-Fergusson (1951). Percobaan dilaksanakan dari bulan Desember 2014 sampai dengan Juli 2015.

Bahan tanaman yang digunakan dalam percobaan adalah 23 aksesi ubi kayu liar yang berasal dari berbagai daerah di Indonesia. Alatalat yang digunkan dalam percobaan adalah pupuk (Urea, SP36 dan $\mathrm{KCl}$ ), cangkul, tugal, patok identitas plot, tali raffia, gunting, meteran, timbangan analitik, jangka sorong, ala tulis, dan kamera.

Metode yang digunakan dalam penelitian ini adalah metode percobaan yang disusun dalam Rancangan Acak Kelompok (RAK). Masing-masing aksesi ditanam dalam dua plot dengan jumlah 23 petak per satu plot. Satu plot terdiri dari lima tanaman. Luas lahan yang dipakai secara keseluruhan yaitu $308 \mathrm{~m}^{2}$ dengan jarak tanam per tanaman $1 \times 2 \mathrm{~m}$ serta kedalaman lubang $15 \mathrm{~cm}$. Sampel yang digunakan terdiri dari tiga tanaman dari setiap petak 
populasi ubi kayu liar. Pengamatan dilakukan pada tiga bulan setelah tanam, enam bulan setelah tanam, sembilan bulan setelah tanam dan panen ketika 12 bulan setelah tanam.

Karakter morfo-agronomi yang diamati berdasarkan deskriptor Fukuda, et al (2010) meliputi karakter kualitatif dan kuantitatif. Analisis keragaman genetik menggunakan analisis multivariat dengan Analisis Komponen Utama dan analisis klaster. Hubungan antara aksesi akan ditampilkan dengan memetakan skor dari nilai $\mathrm{PC}_{1}$ dan $\mathrm{PC}_{2}$ dalam biplot. Dendrogram digunakan untuk mengetahui pola pengelompokan dan keragaman antar aksesi. Data yang diperoleh diolah menggunakan software Ntsys 2.0 pc untuk mendapatkan dendrogram dan nilai eigen value dan eigen vactor dalam analisis komponen utama guna melihat keragaman serta kekerabatan genetik ubi kayu liar dan karakter kontributor atau penciri utama.

\section{Hasil dan Pembahasan}

Pengamatan Karakter Morpho-agronomy Kualitatif Ubi Kayu Liar. Karakter kualitatif adalah karakter pada tanaman yang dikendalikan oleh gen sederhana, lebih mudah diwariskan dan tidak dipengaruhi oleh faktor lingkungan (Baihaki, 1999). Berdasarkan hasil pengamatan karakter kualitatif pada tanaman ubi kayu liar karakter sifat lobed margin tidak memiliki keragaman, sedangkan karakter-karakter lain memiliki keragaman dengan presentase yang berbeda (Tabel 1). Jarak Lobus merupakan salah satu karakter yang diamati pada daun dengan dilihat jarak antar lobus. Nilai retensi dinyatakan dalam halus dan bergelombang.

Karakter warna daun apikal terbagi menjadi tiga warna yaitu hijau muda $(87 \%)$, hijau tua $(4.3 \%)$ dan hijau keungunan (8.7\%). Karakter bulu daun pada daun apikal terbagi menjadi dua yaitu ada sebesar $21.7 \%$ dan tidak ada sebesar $78.7 \%$. Karakter bentuk daun terbagi menjad 4 karakter bentuk yaitu berbentuk bulat panjang $(60.9 \%)$, berbentuk seperti pisau bedah $(8.7 \%)$, berbentuk bulatan telur (21.7\%) dan berbentuk linier $(8.7 \%)$. Karakter warna tangkai daun didominasi oleh karakter warna hijau kemerahan (91.4\%) lalu karakter warna merah dan merah kehijauan dengan masing-masing sebesar $4.3 \%$. Karakter warna daun didominasi oleh karakter warna hijau tua dengan presentase sebesar $69.6 \%$ dan karakter warna hijau muda sebesar $30.4 \%$.
Karakter jumlah jari pada daun didominasi oleh daun yang berjari berjumlah lima dengan presentase $73.9 \%$ lalu daun yang berjari tujuh dan tiga dengan presentase sebesar $21.7 \%$ dan $4.4 \%$. Karakter warna urat daun terbagi menjadi dua karakter warna yaitu warna hijau (91.3\%) dan hijau kemerahan (8.7\%). Karakter orientasi tangkai daun terbagi menjadi tiga kriteria yaitu cenderung ke atas $(47.8 \%)$, cenderung ke bawah $(13 \%)$ dan horizontal (39.2\%). Karakter bunga dibagi menjadi dua karakter yaitu ada (berbunga) sebesar 26,09 \% dan tidak ada (tidak berbunga) $73,91 \%$. Karakter jarak lobus dibagi menjadi dua yaitu halus sebasar $100 \%$ dan tidak halus, dalam pengamatan tidak terdapat jarak lobus yang tidak halus. Karakter retensi daun terbagi menjadi tiga karakter yaitu lebih dari rata-rata $(4.4 \%)$, kurang dari rata-rata $(13 \%)$ dan sedang $(82.6 \%)$.

Pengamatan Karakter Kuantitaif Morphoagronomy Kuantitatif Ubi Kayu Liar. Karakter kuantitatif adalah karakter yang umumnya dikendalikan banyak gen dan merupakan hasil akhir dari suatu proses pertumbuhan. Karakter kuantitatif biasanya berkaitan langsung dengan karakter morfologi dan fisiologi tanaman (Nasir, 2001). Karakter kuantitatif pada tanaman ubi kayu liar meliputi panjang daun lobus tengah, panjang tangkai daun, lebar daun lobus tengah dan rasio perbandingan panjang dan lebar daun lobus tengah. Berdasarkan hasil pengamatan, tidak ada perbedaan nyata yang signifikan pada pengamatan panjang daun lobus tengah dan lebar daun lobus tengah serta rasio perbandingan panjang dan lebar daun lobus tengah (Tabel 2). Pengamatan panjang tangkai daun dinyatakan berbeda nyata pada taraf $5 \%$. Pendugaan pada karakter ini terdapat variasi antara aksesi, sehingga perlu dilakukan pengujian lanjutan guna melihat variasi dengan menggunakan uji lanjut Scott-Knott.

Nilai Koefisien varians (KV) memperlihatkan nilai ketepatan pada suatu percobaan. Nilai KV yang semakin tinggi maka ketepatan suatu percobaan tersebut semakin rendah dan sebaliknya jika nilai $\mathrm{KV}$ semakin rendah makan ketepatan suatu percobaan semakin tinggi. Nilai KV tidak boleh lebih besar dari 20\% karena menurut Gaspersz (1991) menyatakan bahwa nilai KV yang kurang dari 20\% adalah baik, artinya bahwa galat percobaan tersebut relative kecil. Berdasarkan data yang diperoleh dari seluruh karakter kuantitatif yang 20\% adalah baik, artinya bahwa galat percobaan tersebut relative kecil. 


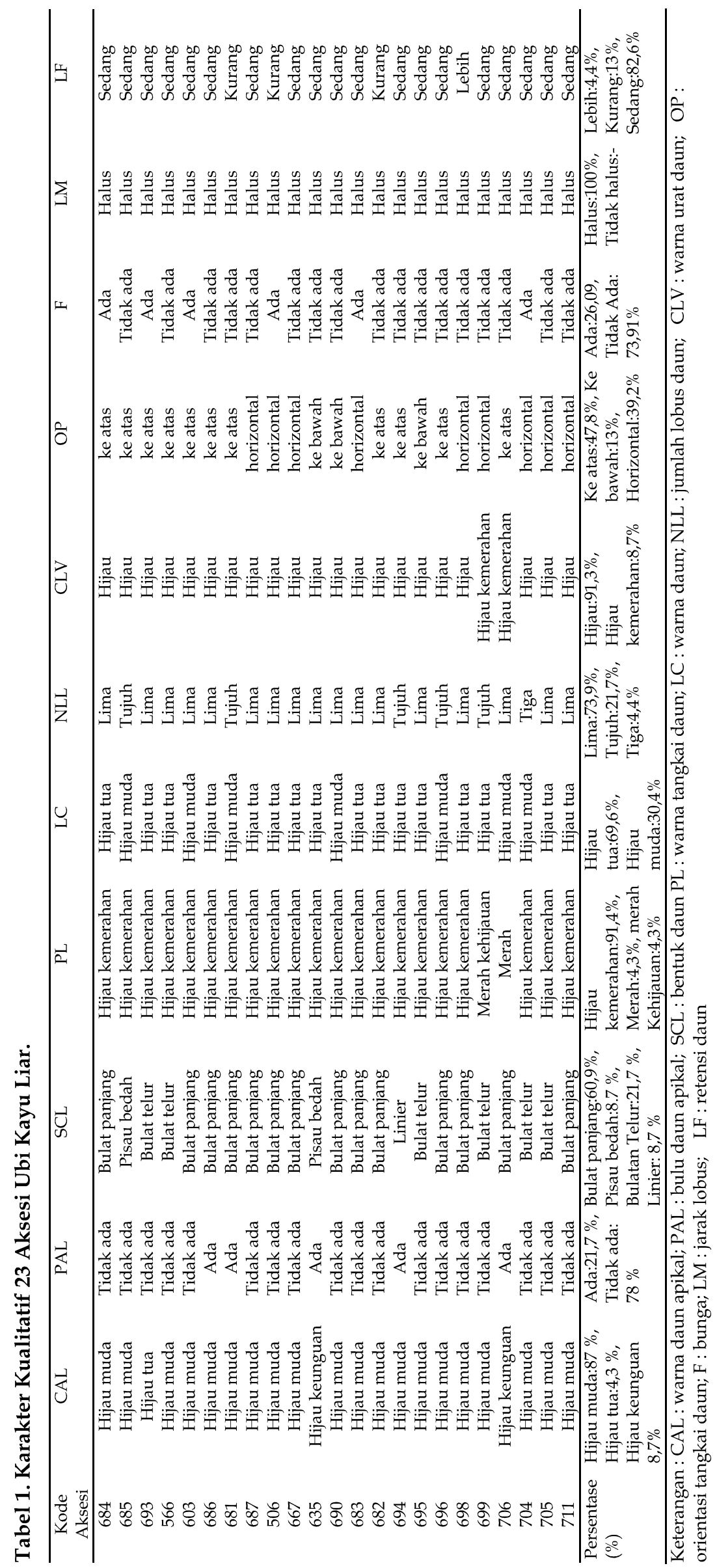


Tabel 2. Karakter Kuantitatif 23 Aksesi Ubi Kayu Liar.

\begin{tabular}{lcccccc}
\hline \multicolumn{1}{c}{ Karakter } & $\begin{array}{c}\text { Nilai } \\
\text { Maksimum }\end{array}$ & $\begin{array}{c}\text { Nilai } \\
\text { Minimum }\end{array}$ & $\begin{array}{c}\text { Rata- } \\
\text { rata }\end{array}$ & F hitung & F tabel & KV $(\%)$ \\
\hline Panjang petiole $(\mathrm{cm})$ & 40.5 & 17 & 28.4 & $2.1^{*}$ & 2 & 15.3 \\
Panjang daun lobus tengah $(\mathrm{cm})$ & 30.2 & 17 & 23 & $1^{\text {ns }}$ & 2 & 11.7 \\
Lebar daun lobus tengah $(\mathrm{cm})$ & 11 & 5.5 & 9.3 & $1.5^{\mathrm{ns}}$ & 2 & 10.9 \\
$\begin{array}{l}\text { Rasio perbandingan panjang daun } \\
\text { dan lebar daun }\end{array}$ & 4.1 & 1.9 & 2.4 & $1.5^{\mathrm{ns}}$ & 2 & 13.4 \\
\hline
\end{tabular}

Tabel 3. Nilai Rata-rata Keseluruhan Karakter Kuantitatif 23 Aksesi Ubi Kayu Liar.

\begin{tabular}{ccccc}
\hline & \multicolumn{3}{c}{ Nilai } \\
\cline { 2 - 5 } Aksesi & Panjang petiole & $\begin{array}{c}\text { Panjang daun lobus } \\
\text { tengah }\end{array}$ & $\begin{array}{c}\text { Lebar daun lobus } \\
\text { tengah }\end{array}$ & $\begin{array}{c}\text { Rasio perbandingan } \\
\text { panjang daun dan } \\
\text { lebar daun }\end{array}$ \\
\hline 684 & 28.25 & 21.5 & 9.1 & 2.35 \\
685 & 33.5 & 22.25 & 8.15 & 2.65 \\
693 & 30.25 & 23 & 9.25 & 2.35 \\
566 & 26.25 & 21.75 & 9.5 & 2.3 \\
603 & 23 & 21.9 & 9.3 & 2.35 \\
686 & 29.85 & 23.5 & 9 & 2.55 \\
681 & 25.25 & 20 & 8.45 & 2.6 \\
687 & 26.5 & 23 & 10.25 & 2.15 \\
506 & 17.5 & 22.5 & 10.5 & 2.05 \\
667 & 25.5 & 23.5 & 9.25 & 2.35 \\
635 & 29.5 & 24.95 & 9.75 & 2.25 \\
690 & 23.5 & 22 & 8.5 & 2.55 \\
683 & 31 & 23.5 & 10.1 & 2.15 \\
682 & 33 & 22.25 & 8.35 & 2.6 \\
694 & 28.25 & 24.65 & 10.5 & 2.05 \\
695 & 35.25 & 27 & 10.5 & 2.1 \\
696 & 24.25 & 22.5 & 10.2 & 2.1 \\
698 & 32 & 23.5 & 9.65 & 2.25 \\
699 & 33 & 21.5 & 6.9 & 3.3 \\
706 & 37.25 & 29.35 & 10.25 & 2.1 \\
704 & 26.5 & 21.5 & 9.25 & 2.35 \\
705 & 29.65 & 23.25 & 8.75 & 2.35 \\
711 & 24.5 & 21.65 & 9.15 & 2.36 \\
\hline Rata-rata & 28.41 & 23.07 & 9.33 & \\
\hline
\end{tabular}

Berdasarkan data yang diperoleh dari seluruh karakter kuantitatif yang berjumlah empat karakter, nilai KV paling tinggi terdapat pada karakter panjang pentiole yaitu sebesar $15.3 \%$, sedangkan nilai KV paling rendah terdapat pada karakter lebar daun lobus tengah dengan nilai sebesar $10.9 \%$ (Tabel 2).

Tidak ada karakter yang memiliki nilai KV lebih tinggi dari 20\%. Perbedaan nilai KV antara karakter pengamatan dipengaruhi oleh adanya keragaman antar aksesi yang digunakan dalam penelitian. Keragaman dalam aksesi yang digunakan dapat dilihat berdasarkan nilai maksimum dan minimum terdapat range cukup besar terutama pada karakter panjang pentiole yang memiliki nilai maksimum $40.5 \mathrm{~cm}$ dan nilai minimum $17 \mathrm{~cm}$. Karakter tersebut memiliki nilai KV yang paling tinggi diantara tiga karakter lainnya yaitu sebesar $15.3 \%$ namun masih dibawah ambang maksimal KV yang dapat dinilai baik menurut Gasperz (1991) yaitu sebesar $20 \%$.

Karakter lebar daun lobus tengah memiliki nilai KV terendah dengan nilai $10.9 \%$. Nilai KV senada dengan range jarak antara nilai maksimum dan minimum dari karakter tersebut yang bernilai masing-masing $11 \mathrm{~cm}$ dan $5.5 \mathrm{~cm}$. Range tersebut sangat sempit sehingga dapat dikatakan bahwa pada karakter lebar daun lobus tengah ini kurang beragam. Besar kecilnya nilai KV dapat bergantung kepada jenis percobaan atau perlakuan, bahan percobaan 
yang digunakan serta karakter apa saja yang diujikan (Gomez, 1995). Nilai KV sangat dibutuhkan guna melihat suatu percobaan apakah dikatakan baik atau tidak. Nilai rata-rata keseluruham karakter kuantitatif dapat dilihat pada Tabel 3.

Berdasarkan Tabel 3, nilai rata-rata hasil pengamatan kuantitatif untuk keempat karakter terdapat beberapa aksesi yang memiliki nilai ratarata lebih tinggi dibandingkan dengan aksesi lain pada beberapa karakter yang diamati. Aksesi 635, 695, dan 706 memiliki nilai lebih tinggi pada tiga karakter yaitu panjang tangkai daun, panjang lobus daun dan lebar lobus daun dibandingkan dengan nilai rata-rata setiap karakternya. Aksesi 695 memiliki panjang tangkai daun paling panjang diantara 22 aksesi lainnya dan aksesi 506 memiliki panjang tungkai terpendek dengan $17.5 \mathrm{~cm}$. Karakter panjang daun, aksesi yang memiliki lobus terpanjang adalah aksesi 706 dengan $29.3 \mathrm{~cm}$ sedangkan yang terpendek adalah aksesi 681 . Karakter lebar daun, aksesi dengan daun tengah terlebar adalah aksesi 506, 694 dan 695, sedangkan yang terpendek adalah aksesi 699 dengan lebar 6.9 $\mathrm{cm}$.

Analisis Komponen Utama dan Analisis Klaster. Keragaman genetik pada ubi kayu liar dianalisis dengan menggunakan PCA, berdasarkan 11 karakter morfo-agronomi. Analisis ini bertujuan untuk mengetahui karakter mana yang memiliki pengaruh terhadap keragaman genetik dari 23 aksesi ubi kayu liar.

Berdasarkan nilai eigen value presentase total keragaman dari karakter yang diamati terhadap 23 aksesi ubi kayu liar (Tabel 4) dan hasil komponen utama (Tabel 5), dapat dilihat bahwa komponen utama $\left(\mathrm{PC}_{1}\right)$ memiliki nilai presentase sebesar $27.98 \%$ yang diberikan oleh karakter bulu pada daun apikal dan bentuk daun lobus tengah dengan nilai kontribusi positif.

Tabel 4. Eigen value dan Presentasi Variasi Karakter Morpho-agronomy dari Lima Sumbu Komponen Utama pada 23 Aksesi Ubi Kayu Liar.

\begin{tabular}{cccc}
\hline PC & Eigen value & $\%$ & Kumulatif \\
\hline 1 & 3.0782 & 27.9836 & 27.9836 \\
2 & 2.1391 & 19.4465 & 47.4301 \\
3 & 1.7588 & 15.9891 & 63.4192 \\
4 & 1.1941 & 10.8553 & 74.2745 \\
5 & 1.0474 & 9.5220 & 83.7965 \\
\hline
\end{tabular}

Nilai posoitif dan negatif pada karakter memiliki artian bahwa karakter dengan nilai kontribusi positif akan menyebabkan terjadinya pengelompokkan namun karakter yang memiliki nilai kontribusi negatif akan mengakibatkan terjadinya pemisahan antar kelompok (Zubair, 2004). Hal tersebut akan mengakibatkan terbentuknya kelompok-kelompok aksesi yang memiliki karakter yang hampir sama.

Nilai analisis komponen utama $\mathrm{PC}_{1}$ pada aksesi-aksesi mempunyai nilai kontribusi variasi total sebesar $63.4192 \%$ pada $\mathrm{PC}_{3}$. Komponen pertama $\left(\mathrm{PC}_{1}\right)$ memiliki nilai kontribusi total sebesar $27.98 \%$. Karakter yang berpengaruh pada PC1 yaitu bulu daun apikal dan bentuk daun. Nilai kontribusi negatif tidak terdapat pada $\mathrm{PC}_{1}$. Komponen kedua $\left(\mathrm{PC}_{2}\right)$ memiliki nilai kontribusi total sebesar $19.45 \%$. Karakter yang berpengaruh pada $\mathrm{PC}_{2}$ yaitu jumlah lobus daun dan jarak lobus (bernilai kontribusi negatif). Komponen ketiga $\left(\mathrm{PC}_{3}\right)$ memiliki nilai total kontribusi sebesar $15.99 \%$. Karakter yang berpengaruh pada $\mathrm{PC}_{3}$ yaitu warna tangkai daun (bernilai kontribusi positif). Menurut Jeffers (1966) nilai eigenvalue 1.0 dan nilai eigenvector yang melebihi nilai 0.7 menunjukkan bahwa pengaruh genetik suatu aksesi memiliki kontribusi yang besar dalam variasi karakter ubi kayu liar.

Tabel 5. Nilai Eigen Vector 11 Karakter Morfoagronomi Hasil Lima Sumbu Utama Komponen Utama pada 23 Aksesi Ubi Kayu Liar.

\begin{tabular}{ccccccc}
\hline No & \multicolumn{1}{c}{ Karakter } & PC 1 & PC 2 & PC 3 & PC 4 & PC 5 \\
\hline 1 & Warna daun & 0.40 & 0.45 & 0.45 & 0.31 & 0.49 \\
& apikal & & & & & \\
2 & Bulu daun apikal & $\mathbf{0 . 7 8}$ & -0.14 & 0.42 & -0.33 & 0.03 \\
3 & Bentuk daun & $\mathbf{0 . 7 8}$ & 0.16 & -0.33 & -0.14 & -0.15 \\
4 & Warna tangkai & -0.53 & 0.02 & $\mathbf{0 . 7 6}$ & -0.16 & -0.10 \\
& daun & & & & & \\
5 & Warna daun & -0.68 & 0.04 & -0.05 & -0.47 & -0.40 \\
6 & Jumlah lobus & 0.41 & $-\mathbf{0 . 7 0}$ & -0.46 & -0.14 & 0.08 \\
& daun & & & & & \\
7 & Warna urat daun & 0.14 & -0.53 & 0.49 & 0.45 & -0.34 \\
8 & Orientasi tangkai & -0.32 & 0.59 & -0.48 & 0.39 & -0.04 \\
& daun & & & & & \\
9 & Bunga & -0.55 & -0.16 & -0.02 & -0.39 & 0.67 \\
10 & Jarak lobus & -0.17 & $-\mathbf{0 . 8 2}$ & -0.11 & 0.24 & 0.18 \\
11 & Retensi daun & -0.58 & -0.28 & -0.07 & 0.37 & 0.07 \\
\hline
\end{tabular}

Ketarangan : PC adalah nilai eigen vector, nilai PC yang bercetak tebal merupakan nilai karakter yang memiliki pengaruh, nilai diskriminant $\geq 0.7$ (Jeffers, 1966).

Hasil Analisis PC ditampilkan dalam bentuk grafik biplot. Menurut Khan (2009) menyebutkan bahwa analisis komponen utama memiliki tujuan untuk melakukan analisis pada karakter-karakter yang berpengaruh terhadap keragaman. Grafik menunjukkan pola sebaran variasi aksesi ubi kayu. Pola penyebaran 23 
aksesi ubi kayu liar berdasarkan karakter morfoagronomi dapat dilihat pada Gambar 1. Grafik penyeberan terdiri dari 4 kuadran. Kuadran pertama terdiri atas aksesi 684 (Jatinangor), 566 (Aceh), 693 (Majalaya), 695 (Bengkulu), 698 (Bengkulu), 711 (Wonosobo) dan 704 (Samarinda). Aksesi 704 dan 695 memiliki posisi terpisah agak berjauhan tapi masih termasuk ke dalam kelompok yang sama. Kelompok kuadran terdiri dari aksesi 687 (Jatinangor)), 683 (Majalengka), 506 (Ciwidey), 699 (Bengkulu), 667 (Bali), 705 (Ciamis) dan 690 (Jatinangor). Kuadran ketiga terdiri dari aksesi nomor 685 (Jatinangor) dan 694 (Manado). Kuadran keempat terdiri dari aksesi nomor 603 (Sidoarjo), 686 (Jatinangor), 682 (Majalengka), 696 (Bengkulu) dan 681 (Lampung). Aksesi nomor 706 asal Sukabumi memiliki jarak genetik kedua terjauh dalam biplot. Aksesi 635 (BB Biogen) terpisah paling jauh dari kelompok yang lain. Terdapat kemungkinan bahwa aksesi 635 berada jauh dari aksesi yang lain .

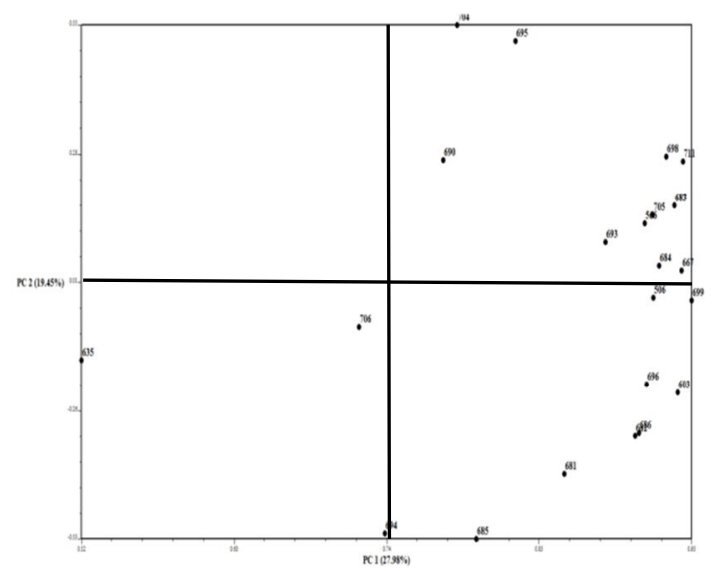

Gambar 1. Biplot Sebaran 23 Aksesi Ubi Kayu Liar Berdasarkan Karakter Morfo-Agronomi.

Hasil analisis komponen utama antara $\mathrm{PC}_{1}$ dan $\mathrm{PC}_{2}$ memiliki nilai kontribusi $47.43 \%$ dari varians 23 aksesi ubi kayu liar. Pola sebaran terlihat pada grafik biplot, untuk menentukan sebarannya digunakan nilai PC yang paling besar memberikan kontribusi. Nilai PC1 dan PC2 memberikan kontribusi terhadap variasi yaitu masing-masing sebesar $27.98 \%$ dan $19.45 \%$. Hasil analisis biplot memperlihatkan bahwa persebaran 23 aksesi ubi kayu liar cukup luas, hal tersebut terlihat pada kelompokkelompok aksesi pada empat kuadran.
Hasil analisis keragaman genetik 23 aksesi ubi kayu liar berdasarkan karakter morfoagronomi menggunakan analisis klaster diperoleh dendogram seperti tampak pada Gambar 2. Gambar tersebut menunjukkan bahwa hasil keragaman genetik yang luas pada beberapa aksesinya dengan jarak euclidean antara 0.00 hingga 3.32 .

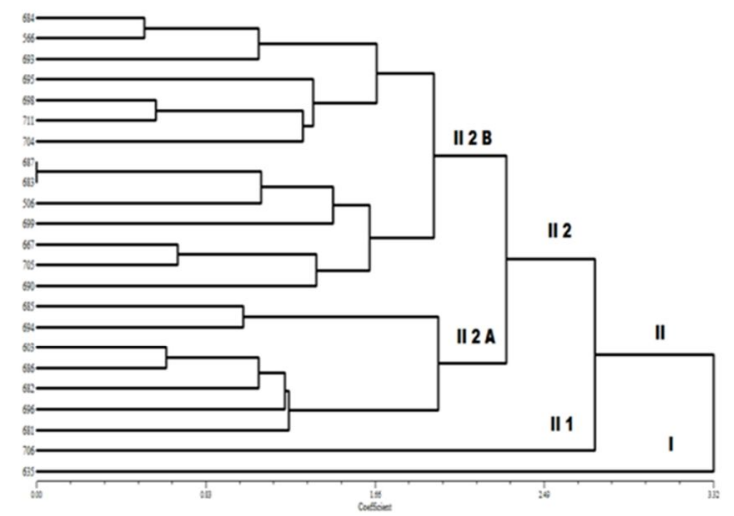

Gambar 2. Dendogram Keragaman Genetik 23 Aksesi Ubi Kayu Liar Berdasarkan Karakter Morfo-Agronomi.

Berdasarkan grafik dendogram dapat dilihat bahwa aksesi yang memiliki koefisien terendah adalah aksesi 687 dan 683 yaitu dengan nilai koefisien 0.00 . Nilai koefisien 0.00 dapat diartikan bahwa kedua aksesi tersebut kemungkinan berasal dari sumber induk yang sama. Aksesi nomor 687 berasal dari Jatinangor sedangkan aksesi 683 berasal dari Majalengka. Pada Tabel 3, dendogram terdiri dari dua klaster utama yaitu I dan II. Adanya aksesi ubi kayu liar yang terdapat pada sub klaster yang sama disebabkan oleh kesamaan karakter morfo-agronomi. Begitu pula letak aksesi sejenis yang tidak berdekatan dengan aksesi sejenisnya dikarenakan adanya ketidakmiripan karakter morfologi pada aksesi tersebut. Klaster I terdiri dari satu aksesi yaitu aksesi 635 dengan nilai euclidean 3.32, nilai tersebut merupakan nilai tertinggi yang terdapat di dalam dendogram, diduga aksesi ini memiliki penampilan fenotip paling berbeda dibandingkan dengan aksesi-aksesi lainnya. Aksesi 635 merupakan aksesi ubi kayu liar yang didapatkan dari BB Biogen, Bogor. Karakter yang mempengaruhi Klaster II terbagi atas dua subklaster yaitu $\mathrm{II}_{1}$ dan $\mathrm{II}_{2}$. Subklaster $\mathrm{II}_{1}$ hanya ada satu aksesi yaitu aksesi 706 yang berasal dari Sukabumi, Jawa Barat. Jarak ecludien dari aksesi ini yaitu 2.73 sehingga pada subklaster ini dapat diduga cukup luas. 
Tabel 3. Klaster Dendogram 23 Aksesi Ubi Kayu Liar Berdasarkan Marka Morfo-Agronomi.

\begin{tabular}{|c|c|c|c|c|c|}
\hline \multirow{22}{*}{ II } & \multirow{21}{*}{ II 2} & \multirow{14}{*}{ II $2 \mathrm{~B}$} & \multirow{7}{*}{ II 2 B-1 } & 684 & Jatinangor I \\
\hline & & & & 566 & Aceh \\
\hline & & & & 693 & Majalaya \\
\hline & & & & 695 & Bengkulu I \\
\hline & & & & 698 & Bengkulu IV \\
\hline & & & & 711 & Wonosobo \\
\hline & & & & 704 & Samarinda \\
\hline & & & \multirow{7}{*}{ II 2 B-2 } & 687 & Jatinangor IV \\
\hline & & & & 683 & Majalengka II \\
\hline & & & & 506 & Ciwidey \\
\hline & & & & 699 & Bengkulu V \\
\hline & & & & 667 & Bali \\
\hline & & & & 705 & Ciamis II \\
\hline & & & & 690 & Jatinangor IX \\
\hline & & \multirow{7}{*}{ II $2 \mathrm{~A}$} & \multirow{2}{*}{ II 2 A-1 } & 685 & Jatinangor II \\
\hline & & & & 694 & Manado \\
\hline & & & \multirow{5}{*}{ II 2 A-2 } & 603 & Sidoarjo \\
\hline & & & & 686 & Jatinangor III \\
\hline & & & & 682 & Majalengka I \\
\hline & & & & 696 & Bengkulu II \\
\hline & & & & 681 & Lampung \\
\hline & \multicolumn{3}{|c|}{ II 1} & 706 & Sukabumi \\
\hline \multicolumn{4}{|c|}{ I } & 635 & BB Biogen \\
\hline Klaster & \multicolumn{3}{|c|}{ Subklaster } & Aksesi & Asal Daerah \\
\hline
\end{tabular}

Subklaster $\mathrm{II}_{2}$ terdapat 21 aksesi ubi kayu liar. Subklaster ini dibagi menjadi dua yaitu $\mathrm{II}_{2-\mathrm{B}}$ dan $\mathrm{II}_{2-\mathrm{A}}$ dengan masing-masing memiliki dua kelompok aksesi dengan jarak euclidean 1.92. Nilai euclidean tersebut dinyatakan luas jika mengikuti acuan Tairo, dkk (2008) yang berpendapat bahwa nilai euclidean di atas 1.00 adalah luas. Subklaster $\mathrm{II}_{2-\mathrm{B}}$ terbagi menjadi dua klaster, pada klaster yang pertama terdapat tujuh aksesi, diantaranya 684, 566, 693, 695, 698, 711 dan 704. Pada pembagian klaster kedua juga terdapat tujuh aksesi yaitu 687, 683, 506, 699, 667, 705 dan 690. Pada klaster ini terdapat dua aksesi dengan nilai euclidean terendah yaitu 0.00 pada aksesi 687 dan 683 . Subklaster $\mathrm{II}_{2-\mathrm{A}}$ juga memiliki dua kelompok, kelompok pertama terdapat aksesi 685 dan 694 sedangkan pada kelompok kedua terdiri atas aksesi 603, 686, 682, 696 dan 681. Data informasi keragaman genetik beberapa aksesi ubi kayu liar dari berbagai wilayah merupakan informasi penting dalam upaya pelestarian plasma nutfah ubi kayu liar dan pemanfaatannya dalam program pemuliaan tanaman. Aksesi tanaman ubi kayu liar yang memiliki keragaman genetik yang luas dapat dijadikan sebagai tetua untuk persilangan.

\section{Kesimpulan dan Saran}

\section{Kesimpulan}

1. Hasil analisis komponen utama $\mathrm{PC}_{1}$ pada aksesi-aksesi ubi kayu liar yang dievaluasi mempunyai kontribusi proporsi variasi total sebesar $63.4192 \%$ pada $\mathrm{PC}_{3}$, karakterkarakter yang berkontribusi terhadap variasi yang terdapat pada aksesi-aksesi tersebut meliputi bulu dau apikal, bentuk daun, jumlah lobus daun, jarak lobus dan warna tangkai daun.

2. Hasil analisis klaster pada 23 aksesi ubi kayu liar menunjukkan keragaman genetik yang luas pada beberapa aksesinya dengan jarak

\section{Saran} euclidean antara 0.00 hingga 3.32 .

Hasil seleksi yang memiliki keragaman genetik yang luas adalah aksesi 695, 635, 694, 690 dan 706, aksesi-aksesi tersebut direkomendasikan untuk menjadi tetua persilangan.

\section{Ucapan Terima Kasih}

Ucapan terima kasih disampaikan kepada Dirjen Dikti melalui skema Penelitian Strategis Nasional (STRANAS) Tahun 2015 atas dukungan finansial dan Ketua DRPMI Unpad yang telah memberi kesempatan untuk melakukan penelitian ini serta semua pihak yang telah membantu.

\section{Daftar Pustaka}

Baihaki, A., T, Herawati dan A, Karuniawan. 1999. Pelestarian Sumber Daya Hayati Pertanian. Diktat Kuliah pada Program Pengembangan Kemampuan Penelitian Tingkat S1 Non Pemuliaan dalam Ilmu dan Teknologi Pemuliaan. Diktat Kuliah. Universitas Padjajaran. Bandung.

Firdausi,N. Z., Samodra, Nugraha, B.S P. Hargono 2013. Pemanfaatan pati singkong karet untuk produksi bioetanol fuel grade melalui proses distilasi-dehidrasi menggunakan zeolit alam. Jurnal Teknologi Kimia dan Industri Universitas Dipenogoro Vol 2 (3), 76-81. 
Fukuda, W.M.G., C.L. Guevara, R. Kawuki, and M.E. Ferguson. 2010. Selected Morphological and Agronomic Descriptors For The characterization of Cassava. p. 119. In IITA Research to Nourish Africa..

Gaspersz, V. 1991. Metode Perancangan Percobaan . Bandung : Armico.

George, P.J. and Reghu, C. P. Collecting Ceara Rubber (Manihot glaziovii muell. Arg.) Germplasm and its Potentialities. Indian Journal of Plant Genetic Resources. World Review of Nutrition and Dietetics, 300-5. doi:10.1159/000360196.

Gomez, K.A. dan Gomez A.A. (1995). Prosedur Statistik untuk Penelitian Pertanian. Edisi Kedua. Jakarta : UI - Press, hal :13 - 16.

Hapsari, M.A dan A. Pramashinta. 2013. Pembuatan bioetanol dari singkong karet (Manihot glaziovii) untuk bahan bakar kompor rumah tangga sebagai upaya mempercepat konversi minyak tanah ke bahan bakar nabati. Jurnal Teknologi Kimia dan Industri, 2 (2). pp. 240-245.

Jeffers J.N.R. Two Case Studies in the Application of Principal Component Analysis. Applied Statistics.1996: p.225-236.

Khan M.A. dan Sabine von W. K. 2009. Relationship Among Different Geographical Groups, Agro-Morphology, Fattu Acid Composition And Rapd Makrker Diversity In Safflower. Genetic Resources and Crop Evolution 56:19-30
Marlitasari, E. 2012. Makalah Menyerbuk Silang Tanaman Alpukat. http://blog.ub.ac.id/ ervianii/2012/06/25/makalah-menyerbuksilang- tanamanalpukat/. 2 Agustus 2012.

Martono, B. 2011. Keragaman genetik, heritabilitas dan korelasi antar karakter kuantitatif nilam (Pogestemon sp.) hasil fusi protoplas. Jurnal Litri 15(1): 9-15.

Nasir, M. 2001. Keragaman Genetik Tanaman, hal 64. Dalam: Makmur, A (Ed). Pengantar Pemuliaan Tanaman. Direktorat Jenderal Pendidikan Tinggi Departemen Pendidikan Nasional. Jakarta.

Schmidt, F. H dan Ferguson, J. H. A. 1951. Rainfall Types Based On Wet and Dry Period Rations for Indonesia With Western New Guinea. Jakarta: Kementrian Perhubungan Meteorologi dan Geofisika.

Sucahyono, D., B. Santoso Radjit, N. Prasetiaswati, dan E. Ginting. 2010. Potensi peningkatan hasil ubi kayu melalui sistim sambung (Mukibat). Iptek Tanaman Pangan, 5 (2) 2010:197-209.

Tairo, F., E. Mneney and A. Kullaya. 2008. Morphological and agronomical characterization of sweet potato (Ipomoea batatas (L.) Lam.) germplasm collection from Tanzania. African J. of Plant Science Vol. 2 (8) pp 077 - 085.

Zubair, M. 2004. Genetik Diversity and Gene Action in Mungbean. Thesis. Faculty of Crop and Food Scienses. University of Arid Agriculture, Rawalpindi. Pakistan. 